PEOPLE: International Journal of Social Sciences

ISSN 2454-5899

Gungaphul E Heeroo, 2022

Volume 7 Issue 3, pp. 189-207

Received: 28th June 2021

Revised: 25 $5^{\text {th }}$ October 2021, 11 th January 2022, 21 st January 2022

Accepted: 25 th January 2022

Date of Publication: 28 th January 2022

DOI- https://doi.org/10.20319/pijss.2022.73.189207

This paper can be cited as Gungaphul, M., E Heeroo, D. S., (2022). Green Buying Behavior Among Mauritian Consumers: Extending the TPB Model. PEOPLE: International Journal of Social Sciences, 7(3), 189-207.

This work is licensed under the CreativeCommons Attribution-NonCommercial 4.0 International License. To view a copy of this license, visit http://creativecommons.org/licenses/by-nc/4.0/ or send a letter to Creative Commons, PO Box 1866, Mountain View, CA 94042, USA.

\title{
GREEN BUYING BEHAVIOR AMONG MAURITIAN CONSUMERS: EXTENDING THE TPB MODEL
}

\section{Mridula Gungaphul}

Department of Management, Faculty of Law and Management, University of Mauritius, Reduit, Mauritius

m.gungaphul@uom.ac.mu

\section{Soheenee Devi Heeroo}

Department of Management, Faculty of Law and Management, University of Mauritius, Reduit, Mauritius

soheenee.heeroo@umail.uom.ac.mu

\begin{abstract}
This study aims to explore the major predictors of green purchase behavior in Mauritius, using an extension of the Theory of Planned Behavior (TPB) model by incorporating advertising and sales promotion as two new factors. A self-administered questionnaire using quota and judgmental sampling survey was conducted to collect data. Hundred and fifty respondents judged to be knowledgeable about environmentally friendly products were approached to participate in the survey. The findings reveal that Mauritians have a strong positive attitude towards the environment. Sales promotion, subjective norms, and attitude towards the environment are found to be significant determinants of green purchase intention. Perceived behavioral control and
\end{abstract}


advertising were identified as not very significant variables. Results further show that there is not enough advertising done concerning green products in Mauritius. A positive relationship between green purchase intention and green purchase behavior was also identified. The results of this study can assist marketers and policymakers in developing more effective strategies when marketing green products in Mauritius to create better awareness and more acceptability of this emerging phenomenon that is a good part of sustainability development.

\section{Keywords}

Green Buying Behavior, TPB, Theory of Planned Behavior, Mauritius, Green Products, Advertising, Sales Promotion

\section{Introduction}

Increasing environmental awareness has led to a rise in demand for eco-friendly products globally (Kumar and Ghodeswar, 2015; Dahlquist, 2021). A rise in community awareness of the environment has occasioned changing behaviors of consumers and has given rise to green purchasing decisions, which do not only benefit the environment but also lead to new business opportunities (Moser, 2015). As Cai, Xie \& Aguilar (2017, p.200) pointed out, "increasing consumer consciousness of the effects on the environment and the society, related with product utilization enables green products to penetrate the market and have a rising market share." Green products may also be considered as part of disruptive innovation that is now causing a drastic change in the business model. Green products can be recognized through different terms such as ecological, toxic-free, renewable, biodegradables (Durif, Boivin, \& Julien, 2010) amongst others. Going green is also being used as a business strategy whereby businesses are being able to distinguish themselves from competitors.

In Mauritius, consumers, as well as the government, are becoming increasingly reactive to the problems that the environment is facing (Khare, 2015). During the last few years, the Mauritian government has been promoting sustainable development through several programmers and legislation. For instance, the "Maurice Ile Durable" program launched in 2008 aims at supporting sustainable development in Mauritius. Policymakers have also imposed a ban on plastic carrier bags from January 2016, to protect the environment including the ocean (Government Information Service, 2016). Plastic containers for take-away food and beverages have been completely banned and entrepreneurs have to use alternatives (although more expensive at times) that are 
biodegradables. Fortunately for main stakeholders, the policy has been applied stagewise and enough time spared for the introduction of various eco-friendlier products on the Mauritian market, examples being organic food, recyclable paper, eco-friendly detergents, electric/hybrid vehicles amongst others to support the sustainable development of the country as well as to meet the demands of consumers. A new Ministry, Ministry of Environment, Solid Waste Management and Climate Change, has been created in 2020 (Government of Mauritius, 2020) to address current, new and emerging environmental challenges posed by climate change and promote a clean environment alongside the protection of the fauna and flora, and management of hazardous wastes amongst others (Government of Mauritius, 2021).

Despite the variety of green products being available on the market and the government's effort to promote a green lifestyle among Mauritian citizens, some people still stick to products, which are not eco-friendly as there is still a lot of pollution in Mauritius. Past studies have revealed that environmental attitudes do not translate into buying behavior (Paço and Raposo, 2010; Gupta and Ogden 2009). The authors further added that research failed to answer the complex question of why consumers do not engage in green purchase despite showing concern about the environment. Juwaheer, Pudaruth and Noyaux (2012) reported that Mauritian consumers show considerable concern and interest for environmental problems conservation of the environment.

From the foregoing, this study seeks to explore the major predictors of green purchase behavior in Mauritius through the application of an extension of the Theory of Planned Behavior (TPB) model by including advertising and sales promotion as two new factors.

The main research questions are:

- To what extent does advertising influence the purchase of green products?

- What impact does sales promotion have on buying behavior of green products?

\section{Literature review}

Studies have revealed that health consciousness and environmental concerns are major factors influencing buying behavior of green products such as organic food, (Khare; 2015; Chen, 2009). Furthermore, environmental consciousness is a key motivator for positively responding to cause-related promotions and eco brands (Phau \& Ong, 2007).

\subsection{Green Products}


Durif, Boivin \& Julien (2010) define a green product within three different perspectives namely academic, industrial and consumers. According to the academic perspective, a green product possesses a design and attributes that make use of recycling resources, and reduce the effect on the environment or minimize the toxic impact on the environment during its whole life cycle (Kumar \& Ghodeswar, 2015). The industrial perspective, views a green product as respecting the "3 Rs" namely "reduce", "reuse" and "recycle"; meaning that it must obtain a certification from an official entity and must not engage in animal testing. For consumers, a green product non-toxic for the environment, health beneficial, socially responsible, and benefits the planet. According to Sun, Wang, Gao \& Li (2018) green products are the products themselves as well as their production processes that are resource-saving, low polluting, low toxic, and recyclable.

\subsection{Theory of Planned Behavior (TPB)}

Significant research has been conducted in various countries on the factors affecting green buying behavior in which multiple factors have been tested. While some studies have adapted dimensions from past studies and have examined their impact on green purchase behavior, others have used the Theory of Planned Behavior (TPB) to determine the factors having a positive influence on green buying behavior. Since the TPB has been successfully applied in several studies to explore the environmental-friendly behavior of consumers (Moser, 2015; Hsu, Chang \& Yansritakul., 2017), this study also adapts this model. As stated by Khare (2015), the Theory of Planned Behavior is an attitude model which is highly utilized to analyze relationships between personal, social norms, and beliefs of individuals with their green purchase.

The Theory of Planned behavior is an extension of the Theory of Reasoned Action (Ajzen \& Fishbein, 1980; Fishbein \& Ajzen, 1975). The reason behind this extension is the limitation of the original model to consider behaviors over which individuals do not have complete volitional control (Ajzen, 1991). Perceived Behavioral Control is the aspect that differs the Theory of Planned Behavior from the Theory of Reasoned Action. The elements of the TPB are Attitudes, Subjective Norms, and Perceived Behavioral Control.

By making some changes to these three predictors, it becomes possible to increase the chance that the individual will develop an intention to perform a certain action and therefore increase the chance of the individual actually performing the action (Francis, 2004). The model of TPB is illustrated in Figure 1 and shows the three variables which predict intention to perform behavior. 


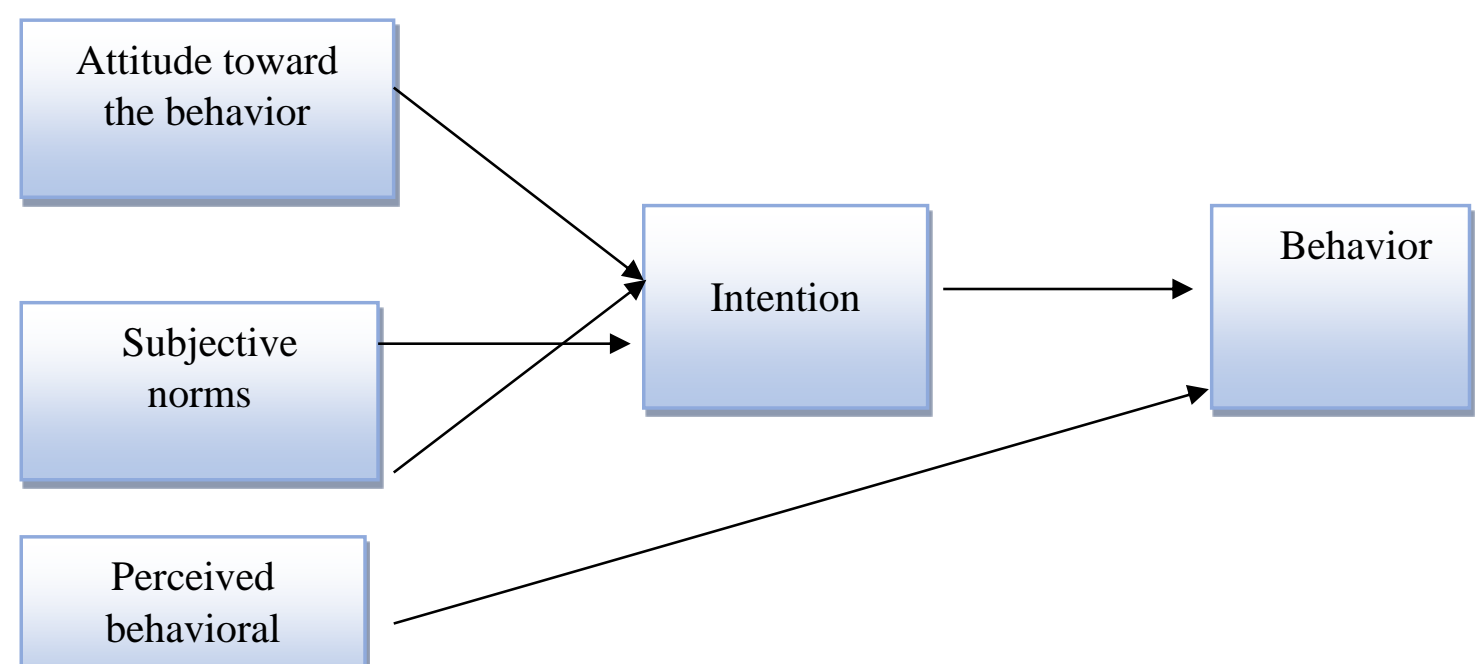

control

Figure 1: Theory of planned behavior

(Source: Ajzen, 1991)

Moser (2015) applied the TBP model to identify the factors which have a major influence on green purchasing behavior and their respective importance. It was found that 'willingness to pay' and personal norms were the two factors that were relevant in predicting green purchasing while attitude was found as being insignificant in influencing green purchasing behavior. Furthermore, in the study of Hsu, Chang \& Yansritakul (2017), the TPB has been utilized to explain the purchasing intentions of green skincare products among consumers in Taiwan. The findings suggest that attitude, perceived behavioral control, environmental consciousness of consumers, and the environmental ethics and beliefs of consumers are factors that significantly influence consumers' intention to use green products. Subjective norms and the social impression were found as having a positive but not significant correlation with consumers' intentions towards the usage of green products.

\subsubsection{Attitude}

Attitude is the level of the favorable or unfavorable judgment of a person towards certain behavior (Ajzen, 1991). Several studies have reported that people's positive attitude towards the environment does not translate into behavior (Paço \& Raposo, 2010; Gupta \& Ogden, 2009). Other studies found that attitude has a positive impact on behavior such as in the food context (Tanner \& Wölfing Kast, 2003) which can be justified by low-cost and facilitating conditions (Moser, 2015). Hence $\mathrm{H}_{1}$ is proposed as follows: 
$\mathrm{H}_{1}$ : Consumers' attitude towards the environment significantly affects green buying intention.

\subsubsection{Subjective Norms}

Subjective norm refers to the perceived social pressure to perform or not to perform a certain behavior (Ajzen, 1991). In a study conducted by Kalafatis et al. (1999), TPB has been used to interpret the effect of outcome beliefs, social and personal norms, referent beliefs, and perceived behavioral control on green purchasing intentions. The findings indicated that social influence and norms were relevant factors in predicting the willingness and intention of Greek and British consumers to buy eco-friendly products. According to Jansson (2011), social norms have a positive impact on consumers' willingness to buy green products. Therefore, $\mathrm{H}_{2}$ is proposed as follows: $\mathrm{H}_{2}$ : Subjective norms significantly affect green buying intention.

\subsubsection{Perceived Behavioral Control}

Perceived behavioral control can be defined as a person's perception of how easy or difficult it is to perform a behavior (Ajzen, 2002). Moser (2015) applied the TBP model to identify the factors which have a major influence on green purchasing behavior and their respective importance. It was found that 'willingness to pay (which replaced PBC) and personal norms were the two factors which were relevant in predicting green purchasing while attitude was found as being insignificant in influencing green purchasing behavior. Therefore $\mathrm{H}_{3}$ is proposed as follows: $\mathrm{H}_{3}$ : Perceived behavioral control significantly affects green buying intention.

\subsection{Advertising}

Advertising is used by numerous enterprises to increase sales which will in turn increase revenue. The aim of advertising can be to inform, persuade or remind customers about a product. Agarwal (2019) opined that marketers ought to select their advertising instrument wisely since it has a lasting impression on customers' minds and helps to create brand awareness and emotional touch at the time of making a purchase. In line with enhancing green movements across the world and with raising awareness of the public about environmental problems, most enterprises have adopted advertisements through media for introducing their green products to green consumers (Rahbar \& Wahid, 2011). Environmental advertisements assist in forming consumers' values and translate these values into the purchase of green products. Therefore, $\mathrm{H}_{4}$ is proposed as follows: $\mathrm{H}_{4}$ : Advertising has a significant impact on green buying intention.

\subsection{Sales Promotions}


Sales promotion is another marketing technique, which is used to incite people to buy a particular product. Sales promotion can be defined as incentives to consumers, designed to stimulate purchase (Jobber, 1995). Sales promotions come in various forms such as discount, gifting, coupons, sampling, bundling, "buy-one-get-one-free", contests amongst others (Bhasin,2017). Blattberg \& Neslin (1990) d,efine a sales promotion as an action-focused marketing event, the purpose of which is to have a direct influence on customers. Till now there are no studies that have focused on the effect of sales promotion on green buying behavior. Hence $\mathrm{H}_{5}$ is proposed as follows:

$\mathrm{H}_{5}$ : Sales promotion has a significant effect on green purchase intention.

\subsection{Intention and Behavior}

Ajzen (1991) stated that intentions to execute some different kinds of behaviors can be anticipated with high precision from attitudes toward the behavior, subjective norms, and perceived behavioral control; and these intentions, together with perceptions of behavioral control, explain away substantial variance in actual behavior. It is assumed that intentions capture the motivational factors that affect a behavior; they denote how far one is inclined to try and the amount of effort one is willing to give to execute the behavior.

In this study, "intention" refers to green buying intention and "behavior" refers to the action of purchasing green products. Therefore, this study will test the link between green buying intention and green purchase action and find out whether these two are consistent. Thus, $\mathrm{H}_{6}$ is proposed as follows:

$\mathrm{H}_{6}$ : There is a significant relationship between green purchase intention and green purchase action.

Therefore an extension of the TBP model will be used for this study as two elements are added to the model, namely advertising and sales promotion. Figure 2 shows the conceptual framework that will be used for this study. The conceptual framework was developed based on and adapted from previous research by Juwaheer et al., (2012); Kumar and Ghodeswar, (2015); Khare, (2015). 


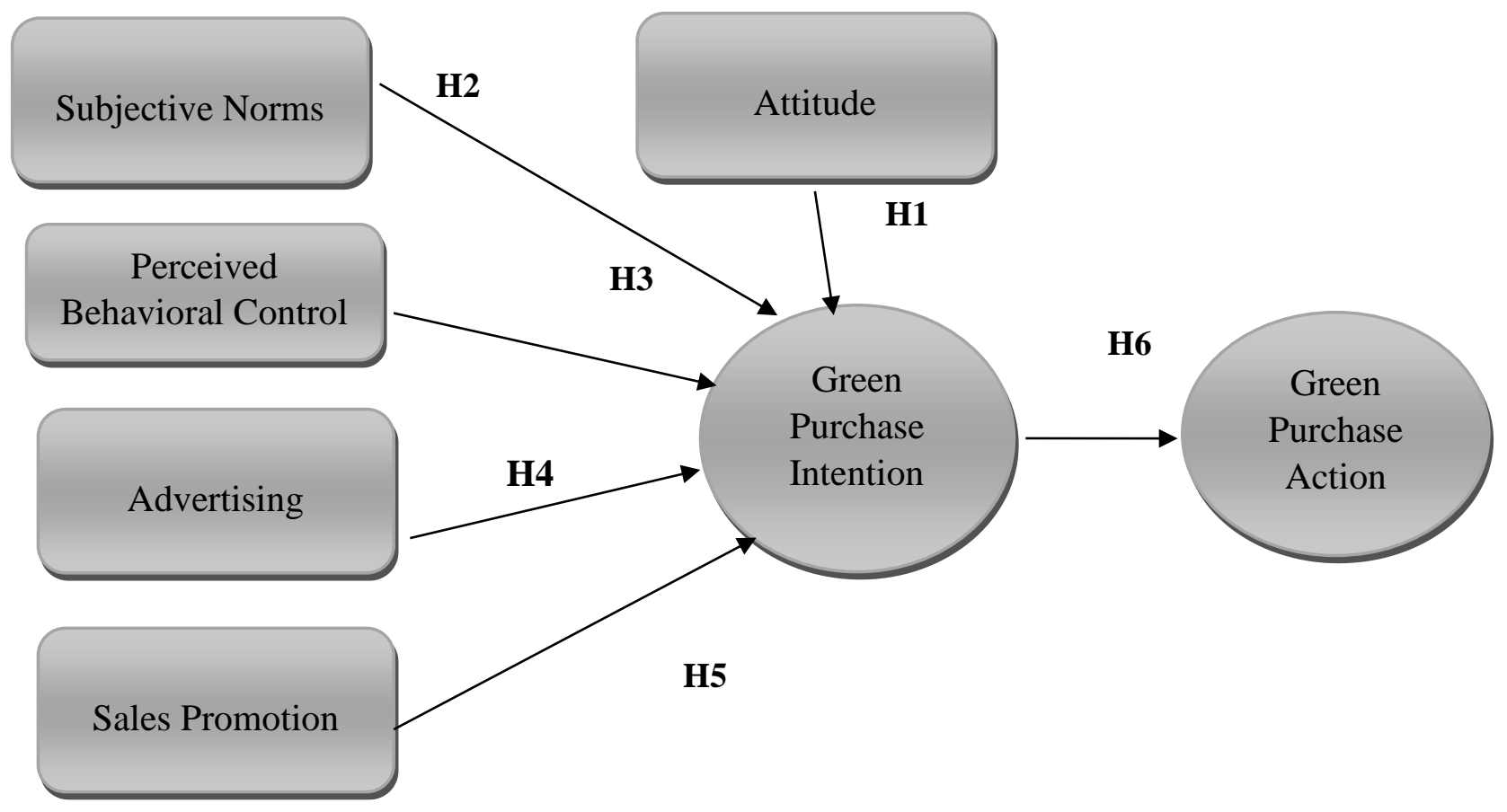

Figure 2: Conceptual framework

(Source: Self)

\section{Research Methodology}

A face to face survey was carried out for data collection. The target population for this study consisted of consumers in Mauritius who could be contacted and were eligible to participate in the survey. It consisted of both male and female Mauritian consumers above the age of 18 . The chosen sample size was 150 . Non-probability sampling was used and respondents were selected based on subjective judgment rather than at random. This sampling method was preferred since one important criterion for eligibility to participate in the survey was knowledge of environmentally friendly products. Participants were informed of the nature of the study and their consent was obtained before administering the questionnaire. A pilot test was initially carried out to test the consistency and accuracy of responses using a small sample displaying similar characteristics to the target population (Hair, Money, Samouel, \& Page, 2007). 
The constructs used included: awareness of consumers about green products; attitude of consumers towards the environment; subjective norms; perceived behavioral control; the effect of advertising, consumers' views on sales promotion; green purchase intention; green purchase action. The Cronbach Alpha test (Table 1) was run to test the reliability and internal consistency of all the multiple-item measures in the Likert-scale questions using coefficient alpha greater than 0.7 (Nunnally, 1978).

Table 1: Reliability Test

\begin{tabular}{|c|c|c|}
\hline Construct & $\begin{array}{c}\text { Cronbach } \\
\text { Alpha }\end{array}$ & $\begin{array}{c}\text { No. of } \\
\text { Items }\end{array}$ \\
\hline Attitude & .752 & 5 \\
\hline Subjective Norms & .833 & 4 \\
\hline Perceived Behavioral Control & .862 & 4 \\
\hline Advertising & .708 & 4 \\
\hline Sales Promotion & .738 & 5 \\
\hline Green Purchase Intention & .882 & 5 \\
\hline Green Purchase Action & .889 & 5 \\
\hline
\end{tabular}

(Source: Authors' SPSS Analysis)

\section{Analysis and Findings}

The data collected from a sample of 150 respondents were analyzed using Microsoft Excel and IBM SPSS software. The profile of the respondents was analyzed and reported. Inferential statistics were used for hypotheses testing. The results and findings are presented below.

\subsection{Demographic Profile}

$49 \%$ of the respondents were male and $51 \%$ were female. $20.7 \%$ of the respondents were in the age group of $18-25,20 \%$ were in the age group of $26-35,20 \%$ were in the age group of 36 $45,20 \%$ were in the age group of $46-55$ and $19.3 \%$ were above 55 . The majority of respondents have attained tertiary-level education (36\%). This is followed by respondents with secondary education which represents $33.3 \%$ of the total number of respondents. This means that the majority of respondents have a considerable level of education. $4.7 \%$ of the respondents had no formal education and concerned mainly those above 55 which may be due to the absence of opportunities (mainly financial issues) to attend school. A great majority (68\%) of respondents are employed while $20 \%$ are students. $10.7 \%$ of the respondents are retired with $1.3 \%$ being unemployed. $46.7 \%$ of respondents earn a monthly household income of Rs 20, 001 - Rs 30, 000. 20.7\% earn a 
monthly household income of Rs 30, 001 - Rs 40, 000. 14\% earn less than Rs 10, 000, and 2.7\% earn above Rs 50, 000. Only $1.3 \%$ of the respondents earn Rs 400001 - Rs 50, 000. This implies that the majority of the respondents are middle-income earners, that is, Rs 20, $001-$ Rs 30, 000.

\subsection{Hypotheses Testing} 2 to 7.

The hypotheses formulated in this study were tested and the results are presented in Tables

Table 2: Model Summary

\begin{tabular}{|llcll|}
\hline Model & $\mathrm{R}$ & R Square & Adjusted R Square & $\begin{array}{l}\text { Std. Error of the } \\
\text { Estimate }\end{array}$ \\
\hline 1 & 0.443 & 0.196 & 0.168 & 0.40678 \\
\hline
\end{tabular}

(Source: Authors' SPSS Analysis)

Table 3: ANOVA

\begin{tabular}{|cc|c|c|c|c|c|}
\hline \multirow{2}{*}{ Model } & $\begin{array}{c}\text { Sum of } \\
\text { Squares }\end{array}$ & Df & Mean Square & F & Sig. \\
\hline \multirow{4}{*}{1} & Regression & 5.822 & 5 & 1.164 & 7.037 & .000 \\
& Residual & 23.827 & 144 & .165 & & \\
& Total & 29.649 & 149 & & & \\
\hline
\end{tabular}

(Source: Authors' SPSS Analysis)

Table 4: Regression Coefficients for the Predictors

\begin{tabular}{|c|c|c|c|c|c|}
\hline \multirow[t]{2}{*}{ Model } & \multicolumn{2}{|c|}{$\begin{array}{c}\text { Unstandardized } \\
\text { Coefficients }\end{array}$} & $\begin{array}{l}\text { Standardized } \\
\text { Coefficients }\end{array}$ & \multirow[t]{2}{*}{$\mathrm{t}$} & \multirow[t]{2}{*}{ Sig. } \\
\hline & $\mathrm{B}$ & Std. Error & Beta & & \\
\hline (Constant) & 1.072 & .487 & & 2.204 & .029 \\
\hline $\begin{array}{l}\text { Attitude towards the } \\
\text { environment }\end{array}$ & .201 & .081 & .212 & 2.480 & .014 \\
\hline Subjective Norms & .178 & .061 & .318 & 2.916 & .004 \\
\hline $\begin{array}{l}\text { Perceived Behavioral } \\
\text { Control }\end{array}$ & .048 & .063 & .076 & .762 & .447 \\
\hline Advertising & .002 & .055 & .003 & .038 & .970 \\
\hline Sales Promotion & .294 & .076 & .380 & 3.857 & .000 \\
\hline
\end{tabular}

(Source: Authors' SPSS Analysis)

A multiple linear regression analysis was conducted to predict green purchase intention based on attitude towards the environment, subjective norms, perceived behavioral control, adverting, and sales promotion. A significant regression equation was found $(\mathrm{F}(5,144)=7.04, \mathrm{p}$ 
$=0.000<0.05)\left(\right.$ Table 3) with an $\mathrm{R}^{2}$ of 0.196 (Table 2). The regression model, therefore, explains $19.6 \%$ of variance in green purchase intention.

According to the result (Table 4), green purchase intention is increased by 0.201 units for each unit increase in attitude towards the environment, by 0.178 units for each unit increase in subjective norms, and by 0.294 units for each unit increase in sales promotion. Based on the analysis, attitude towards the environment $(\mathrm{p}=0.014<0.05)$, subjective norms $(\mathrm{p}=0.004<0.05)$, and sales promotion $(\mathrm{p}=0.000<0.05)$ have been found to be significant determinants of green purchase intention. Thus, there is enough confidence that the statistics calculated based on the sample are not due to sampling error and can be intended for the study population. However, perceived behavioral control $(\mathrm{p}=0.447>0.05)$ and advertising $(\mathrm{p}=0.970>0.05)$ are insignificant variables. Moreover, sales promotion has been found to have the greatest influence of green purchase intention with a $\beta$ value of 0.380 , followed by subjective norms $(\beta=0.318)$ while attitude towards the environment has the lowest influence on green purchase intention $(\beta=0.212)$.

This implies that the hypotheses $\mathrm{H}_{1}, \mathrm{H}_{2}$, and $\mathrm{H}_{5}$ are accepted while $\mathrm{H}_{3}$ and $\mathrm{H}_{4}$ are rejected. Hence, Green Purchase Intention $=1.072+0.201$ (Attitude) +0.178 (Subjective norms $)+0.294$ (Sales promotion) $+\varepsilon$

For the sixth hypothesis, a simple linear regression analysis was calculated to predict green purchase action based on green purchase intention. The results demonstrate a significant regression equation $(\mathrm{F}(1,148)=8.34, \mathrm{p}=0.004<0.05)$, with an $\mathrm{R}^{2}$ of $0.153 .15 .3 \%$ of variance in green purchase action is therefore explained by the regression model (Table 5). The dependent variable was Green Purchase Action and the Predictor was Green Purchase Intention.

Table 5: Model Summary

\begin{tabular}{|c|c|c|c|c|}
\hline Model & R & R Square & Adjusted R Square & Std. Error of the Estimate \\
\hline 1 & .231 & 0.153 & .047 & .79860 \\
\hline
\end{tabular}

(Source: Authors' SPSS Analysis)

Table 6: ANOVA

\begin{tabular}{|cc|c|c|c|c|c|}
\hline \multicolumn{2}{|c|}{ Model } & $\begin{array}{c}\text { Sum of } \\
\text { Squares }\end{array}$ & df & Mean Square & F & Sig. \\
\hline \multirow{2}{*}{1} & Regression & 5.318 & 1 & 5.318 & 8.339 & .004 \\
& Residual & 94.389 & 148 & .638 & & \\
& Total & 99.707 & 149 & & & \\
\hline
\end{tabular}

(Source: Authors' SPSS Analysis') 
Table 7: Regression Coefficients for the Predictor

\begin{tabular}{|c|c|c|c|c|c|c|}
\hline & \multirow[t]{2}{*}{ Model } & \multicolumn{2}{|c|}{$\begin{array}{l}\text { Unstandardized } \\
\text { Coefficients }\end{array}$} & $\begin{array}{c}\text { Standardized } \\
\text { Coefficients }\end{array}$ & \multirow[t]{2}{*}{$\mathrm{t}$} & \multirow[t]{2}{*}{ Sig. } \\
\hline & & B & Std. Error & Beta & & \\
\hline & (Constant) & .599 & .561 & & 1.067 & .288 \\
\hline 1 & $\begin{array}{l}\text { Green Purchase } \\
\text { Intention }\end{array}$ & .424 & .147 & .231 & 2.888 & .004 \\
\hline
\end{tabular}

(Source: Authors' SPSS Analysis)

Green purchase action is increased by 0.424 unit for each unit increase in purchase intention. Based on the analysis green purchase intention $(p=0.004<0.05)$ has been found to be a significant determinant of green purchase action (Table 6). Therefore, we can be confident enough that the result obtained is not due to chance.

Thus, $\mathrm{H}_{6}$ is accepted

Green Purchase Action $=0.599+0.424($ Green purchase intention $)+\varepsilon($ Table 7$)$

\section{Discussion}

According to the survey, it was found that the majority of people in Mauritius have a strong positive attitude towards the environment. This tallies with the findings of Juwaheer, Pudaruth \& Noyaux (2012) who found that Mauritian consumers show considerable concern for environmental problems and also display interest in the conservation of the environment. The positive attitude of consumers towards the environment has also been found to affect green purchase intention. This supports the findings of Phau and Ong, (2007); Khare (2015); Chen (2009); who also found that environmental consciousness has a positive impact on green purchase behavior. Focusing on the level of environmental knowledge of customers, it comes to the surface that customers in developing countries have lesser knowledge in comparison to the customers in developed countries. This causes concern for the marketing departments in organizations since different customer niches demand different marketing solutions to influence their buying decision.

Subjective norms were identified as the second factor having the most influence on green purchasing intention. This is in accordance with the study of Khare (2015) which observed that social conformance is an important factor in determining the green purchasing behavior of 
consumers. The findings also align with those of Jansson (2011) who identified social norms as having a positive impact on consumers' willingness to buy green products.

Perceived behavioral control does not affect green buying intention. However, this contradicts the findings of Moser (2015) who applied the TBP model to identify the factors having major influences on green purchasing behavior. His study found that 'willingness to pay' (which replaced PBC) is a relevant factor in predicting green purchasing. The present findings show that there is no relationship between advertising and green buying intention. This contradicts the findings of Baldwin (1993) who stated that environmental advertisements assist in forming consumers' values and translate these values into the buying of eco-friendly products. It is found that most people disagree with the fact that there is enough advertising on green products in Mauritius. This might have prevented a genuine evaluation of the effect of advertising on green purchase behavior as they are not exposed to enough adverts on green products. This is an implication for marketers, who should consider developing more green adverts and more so in line with the findings of Ali (2021) who observed that customers in developing countries have lesser knowledge in comparison to the customers in developed countries regarding green products and hence encouraged marketing departments in organizations to put more emphasis on green products in their marketing communication.

According to the survey findings, sales promotion has been identified as the factor having the greatest influence on green purchase intention among all the other factors that were tested. Sales promotion encourages customers to try new brands and also provides customers with more value for money, therefore having an impact on green purchase intention. As no such study has concentrated on sales promotion in relation to green purchase intention, this is a new factor that can be further studied in detail in the future.

In this study, green purchase intention has been identified as having an impact of green purchase action. This means that green purchase intention eventually translates into green purchase action.

\section{Recommendations}

The analysis and findings have shed light on the factors that have an impact on the green buying intention of Mauritian consumers and clarifications have also been made on some issues related with green purchase. 
Marketers should pay special attention to the packaging of green products to make the ecolabel clear and more visible to customers. Educating customers on eco-labels could be an effective strategy to increase knowledge on this issue. Customers can be educated on the different eco-labels that exist in Mauritius and what do these labels mean. When customers familiarize themselves with eco-labels, it will be easier for them to distinguish between a green product and a non-green product. According to the study conducted by Juwaheer, Pudaruth and Noyaux (2012) in Mauritius, eco-label was found to be an important factor affecting green purchasing behavior. Therefore, working on the above-mentioned strategies can be fruitful for marketers.

The findings show that most people do not have control over their behavior and think that it is difficult to execute the behavior, that is, green purchase. This means that some people will not buy green products even if they want to because some factors are making it difficult for them to make the purchase. Furthermore, the survey has also revealed that price is the first factor on which most people disagree as they do not find the price of green products affordable. This implies that due to the high price of green products, some people do not make green purchases. Since a strong positive attitude towards the environment was found among Mauritian consumers, some of them might be willing to buy green products to contribute to the protection of the environment but are not doing so due to the high price of green products. Therefore, marketers should try to lower the price of green products to make them affordable to everyone and also encourage more people to buy green products. Alternatively, as per the study of Changjoon, Lim and Byoungchun (2021), high prices may increase purchase intentions when customers are provided with genuine and credible information about green products.

The survey revealed that sales promotion positively affects green purchase intention. Consumers already have a positive attitude towards the environment and have an interest in its protection. Some stimulation from marketers, for example, samples of green products can be offered to consumers so that they can try the product. By so doing, consumers get the opportunity to try and evaluate the product without any risk involved and after having experienced its benefits, they might continue buying it in the future.

Another factor that has been found as a barrier to green purchase is the inability to identify green products in retail stores as most people disagree with the fact that it is easy to identify green products. Dahlquist (2021) also suggests how knowledge redundancy among other factors acts as a barrier towards the choice and purchase of green products. To address this issue, retail stores 
such as supermarkets can have a special section where all green products can be displayed. In this section, only eco-friendly products will be displayed. This will facilitate the task of people who want to purchase green products as they will not have to move around the store to find green products. People who want to buy green products can go directly to this section which can be named the "green section". Moreover, this will enable green products to gain more visibility in stores as they will not be mixed with other products on the shelves and help customers make more informed decisions through such green marketing strategies (Ali, 2021).

Marketers should also focus on developing more advertisements on eco-friendly products. This will help to increase awareness of green products and when people will be more exposed to these adverts, this will help them to retain green brands in their minds. As proposed by (Luo, Chen $\&$ Chea 2020) positive EWOM (electronic word of the mouth) on social media, such as Facebook, must be encouraged to build up a positive reputation and craft appropriate marketing strategies for green products business growth.

From the point of view of policymakers, (Dike, Toby \& Amaramiro (2021) recommend the enactment of appropriate laws that will promote sustainable peace and enduring development. This will ensure that green products and processes for making them will continue to be on the government agenda and thus create further business opportunities that are properly communicated to stakeholders for appropriate action, in line with what is being currently promoted such as lower road tax for electric/hybrid vehicles as well as low-interest loans for the purchase of the same.

Along the same vein, Gule (2021) recommends countries to invest in clean energy processes to contain the $\mathrm{CO} 2$ (Carbon dioxide) emissions and adopt policies that promote the use

of environmentally friendly technologies to pursue sustainable development goals. It is very interesting to note that Mauritius has already embarked on such paths to a fair amount of success and promoting the island for various businesses incorporates these themes in the advertising and sales promotion messages.

It can be said that in Mauritius there are both users and non-users of green products. There are some have adopted green products while others have not due to some barriers that have been discussed in this study. Some strategies have also been recommended that can help in converting non-users of green products into users and also to encourage people to use more green products.

\section{Conclusion, Limitations and Suggestions for Future Research}


It is found that sales promotion, attitude towards the environment and subjective norms were identified as factors that have a significant influence on green purchasing intention. Mauritians have a positive attitude towards the environment which is consistent with their buying intention. Sales promotion was found to have a positive influence on green purchase intention while advertising does not affect green purchase intention. Therefore, by implementing the suggested strategies, marketers can better promote eco-friendly products and increase the number of green products consumers in Mauritius. From a Mauritian citizen's point of view, this can decrease the level of pollution in Mauritius, making it a better place to live for all the citizens and making them proud of their country.

Concerning the limitations of this research, the study is based on the TPB model and two additional factors namely sales promotion and advertising. Other factors were not tested such as environmental awareness, personal values and norms, green product experience, green selfidentity, and socio-demographic factors. There is limited in-depth insight gathered from the respondents since the data collection method was mainly quantitative.

Further research can analyze the effect of other factors such as environmental awareness, personal values and norms, green product experience, green self-identity, and socio-demographic factors on green purchase intention among Mauritian consumers. As the study is only quantitative, further research can be of qualitative nature which will enable further exploration of green buying behavior and other factors affecting green purchasing intention can be discovered. Moreover, larger sample size can be taken as it will enable a more precise representation of the study population.

\section{REFERENCES}

Agarwal, M. V. (2019). An empirical study on consumer buying behaviour of selected hosiery products. PEOPLE: International Journal of Social Sciences, 5(1), 242-253. https://doi.org/10.20319/pijss.2019.51.242253

Ajzen, I., (1985). Action Control: From Cognition to Behavior. Springer Berlin Heidelberg, 1985., 11-39. https://doi.org/10.1007/978-3-642-69746-3 2

Ajzen, I., (1991). The Theory of Planned Behavior. Organizational Behavior and Human Decision Processes, 50, 179-211. https://doi.org/10.1016/0749-5978(91)90020-T 
Ajzen, I., (2002). Perceived Behavioral Control, Self-Efficacy, Locus of Control, and the Theory of Planned Behavior. Journal ofApplied Social Psychology, 32(4), 665-683. https://doi.org/10.1111/j.1559-1816.2002.tb00236.x

Ajzenn, I and Fishbein, M., (1975), Uuderstanding attitudes and predicting social behavior. Englewood Cliffs, NJ: Prentice-Hall.

Ali, M. (2021). A social practice theory perspective on green marketing initiatives and green purchase behavior. Cross-Cultural \& Strategic Management, 28(4), 815-838. https://doi.org/10.1108/CCSM-12-2020-0241

Bhasin, H., (2017). What is Sales promotion and what are the types of sales promotions? [Online] Available at: https://www.marketing91.com/what-is-sales-promotion/ [Accessed 28 November 2018].

Blattberg, R. C., \& Neslin, S. A. (1989). Sales promotion- the long and the short of it. Marketing Letters, 1(1), 81-97. https://doi.org/10.1007/BF00436151

Cai, Z., Xie, Y. \& Aguilar, F. X., (2017). Eco-label credibility and retailer effects on green product purchasing. Forest Policy and Economics, p. 200-208. https://doi.org/10.1016/j.forpol.2017.04.001

Changjoon Lee, Soyoun Lim, \& Byoungchun Ha. (2021). Green Supply Chain Management and Its Impact on Consumer Purchase Decision as a Marketing Strategy: Applying the Theory of Planned Behavior. Sustainability, 13(10971), 10971. https://doi.org/10.3390/su131910971

Dahlquist, S. H. (2021). How green product demands influence industrial buyer/seller relationships, knowledge, and marketing dynamic capabilities. Journal of Business Research, 136, 402-413. https://doi.org/10.1016/i.jbusres.2021.07.045

Dike, S. C., Toby, B. G., \& Amaramiro, A. S. (2021). Amnesty programme, enabling laws and sustainable development in Niger Delta of Nigeria. PEOPLE: International Journal of Social Sciences, 7(1), 57-74. https://doi.org/10.20319/pijss.2021.71.5774

Durif, F., Boivin, C. \& Julien, C., (2010). In Search of a Green Product Definition. Innovative Marketing (hybrid), 6(1), 25-31.

Fishbein, M., and Ajzenn, I. (1975) Belief, Attitude, Intention and Behaviour. Reading, MA: Addison-Wesley. 
Francis, J. J.., (2004). Constructing questionnaires based on the Theory of Planned Behaviour. Quality of life and management of living resources, 7-30.

Government Information Service., (2016). Mauritius bans the use of plastic bags. [Online] Available at: http://www.govmu.org/English/News/Pages/Mauritius-bans-the-use-ofplastic-bags.aspx [Accessed 20 August 2019].

Government of Mauritius,(2020). Annual Report, Ministry of Environment, Solid Wate of Management and Climate Change. [Online] https://environment.govmu.org/Lists/AnnualReports/Attachments/4/ANNUAL\%20REPO RT\%202019-2020.pdf

Government of Mauritius, 2021, https://govmu.org/EN/infoservices/environment/Pages/sustainable.aspx (Accessed on 19/10/2021)

Gule, L. (2021). The effects of FDI and economic growth on CO2 emissions in SADC.

PEOPLE: International Journal of Social Sciences, 7(1), 75-87. https://doi.org/10.20319/pijss.2021.71.7587

Gupta, S. \& Ogden, D. T., (2009). To buy or not to buy? A social dilemma. Journal of Consumer Marketing, 26(6), p. 376-391. https://doi.org/10.1108/07363760910988201

Hair, Joseph F, Arthur H. Money, Phillip Samouel, and Mike Page. Research Methods for Business. Chichester: John Wiley and Sons, 2007

Hsu, C.-L., Chang, C.-Y. \& Yansritakul, C., (2017). Exploring purchase intention of green skincare products using the theory of planned behavior: Testing the moderating effects of country of origin and price sensitivity. Journal of Retailing and Consumer Services, 34, 145-152. https://doi.org/10.1016/j.jretconser.2016.10.006

Jansson, J., (2011). Consumer Eco-Innovation Adoption:. Business Strategy and the Environment, 20, 192-210. https://doi.org/10.1002/bse.690

Jobber, D., (1995). Principles and Practice of Marketing. Maidenhead: McGraw-Hill Book Company Europe.

Juwaheer, T. D., Pudaruth, S. \& Noyaux, M. M. E. N., (2012). Analysing the impact of green. World Journal of Entrepreneurship,, 8(1), pp. 36-59. https://doi.org/10.1108/20425961211221615 
Kalafatis, S. P., Pollard, M., East, R. \& Tsogas, M. H., (1999). Green marketing and Ajzen's. Journal of Consumer Marketing, 16(5), pp. 441-460. https://doi.org/10.1108/07363769910289550

Khare, A., 2015. Antecedents to green buying behaviour: a study on consumers in an emerging economy. Marketing Intelligence \& Planning, 33 (3), . 2-20. https://doi.org/10.1108/MIP05-2014-0083

Kumar, P. \& Ghodeswar, B. M., (2015). Factors affecting consumers' green product purchase decisions. Marketing Intelligence \& Planning, 33(3), 330 - 347. https://doi.org/10.1108/MIP-03-2014-0068

Luo, M. M., Chen, M. W., \& Chea, S. (2020). Facebook E-WOM marketing strategy: a social support theory perspective. PEOPLE: International Journal of Social Sciences, 6(1), 501-511. https://doi.org/10.20319/pijss.2020.61.501511 https://doi.org/10.20319/pijss.2020.61.501511

Moser, A. K., (2015). Thinking green, buying green? Drivers of pro-environmental purchasing behavior. Journal of Consumer Marketing, 32(3), 167 - 175. https://doi.org/10.1108/JCM10-2014-1179

Nunnally, J.C. (1978) Psychometric theory. 2nd Edition, McGraw-Hill, New York.

Paço, A. M. F. d. \& Raposo, M. L. B., (2010). Green consumer market segmentation: empirical findings. International Journal of Consumer Studies, 429-436. https://doi.org/10.1111/j.1470-6431.2010.00869.x

Phau, I. \& Ong, D., (2007). An investigation of the effects of environmental claims in promotional. Marketing Intelligence \& Planning, 25(7), 772-788. https://doi.org/10.1108/02634500710834214

Rahbar, E. \& Wahid, N. A., (2011). Investigation of green marketing tools' effect on consumers' purchase behavior. Business Strategies Series, 12(2), 73-83. https://doi.org/10.1108/17515631111114877

Sun, Y., Wang, S., Gao, L., \& Li, J. (2018). Unearthing the effects of personality traits on consumer's attitude and intention to buy green products. Natural Hazards, 93 (1), 299 314. https://doi.org/10.1007/s11069-018-3301-4

Tanner, C. and Wolfing K., S. (2003), "Promoting sustainable consumption: determinants of green purchases by Swiss consumers", Psychology and Marketing, 20 No. 10, 883-903. https://doi.org/10.1002/mar.10101 